IFN Working Paper No. 702, 2007

\title{
Wholesale Price Discrimination and Parallel Imports
}

Mattias Ganslandt and Keith E. Maskus 


\title{
Wholesale Price Discrimination and Parallel Imports*
}

\author{
Mattias Ganslandt ${ }^{\dagger} \quad$ Keith E. Maskus ${ }^{\ddagger}$
}

2007-03-05

\begin{abstract}
We develop a model of vertical pricing in which an original manufacturer sets wholesale prices in two markets integrated at the distributor level by parallel imports (PI). In this context we show that if competition policy requires uniform wholesale prices across locations it would push retail prices toward convergence as transportation costs fall. However, these retail prices could be higher than those induced without restrictions on prices charged to distributors. Thus, the competition policy may not be optimal for consumer welfare.

Keywords: Vertical Restraints; Parallel Imports; Market Integration; Price Discrimination; Competition Policy
\end{abstract}

JEL Codes: F15, L14, K21

\footnotetext{
*Ganslandt is grateful to the Tom Hedelius and Jan Wallander foundation for financial support. We are also grateful for comments from Jim Markusen, Lars Persson and seminar participants at Lund University, NOITS, the Competition Policy Conference in Stockholm and the CEPR Competition Policy in International Markets Symposium and Conference in Brussels, Dec 2005.

${ }^{\dagger}$ IFN, Research Institute of Industrial Economics, Box 55665, SE-102 15 Stockholm, Sweden and University of Colorado (Visiting professor), 256 UCB, Boulder, CO 80309-0256, USA, Phone: (303) 492-7588, e-mail: mattias.ganslandt@colorado.edu, web: www.mattiasganslandt.com.

‡Department of Economics, Campus Box 256, University of Colorado, Boulder, CO 803090256, Phone (303) 4927588, e-mail: keith.maskus@colorado.edu
} 


\section{Introduction}

Competition law in the European Union (EU) has two equally important objectives. One aim is to encourage competition among firms, which is presumed to achieve maximum consumer benefits. The second is to protect the unimpeded functioning of the EU's single market, by both reducing costs of engaging in intra-market trade and safeguarding the legality of arbitrage through parallel imports. Firms are not permitted to partition the European market, nor to discriminate among consumers based on their nationality or location. This latter imperative in European law is based on the underlying presumption that market integration is central for enhancing competition. Thus, these two objectives generally are seen to be in concert with one another.

Similar comments apply to U.S. case law, emanating from interpretations of the Robinson-Patman Act, which regulates price discrimination. In the United States manufacturers frequently use independent distributors, who are typically awarded exclusive territories within regions or states. The Robinson-Patman Act places some restrictions on the ability of original manufacturers to charge different wholesale prices to different distributors. Those manufacturers might wish to do so to cope with the problem of gray-market trade, which is unauthorized trade across territories in parallel channels. That trade reflects the significant integration of regional markets within the country, itself a goal enshrined in the Commerce Clause of the Constitution, and competition law seeks to safeguard that integration.

To clarify, parallel imports (PI) are goods placed legitimately onto the market in one country but subsequently imported into another country without the authorization of the holder of intellectual property protection (patent, copyright, or trademark) in the latter market. The legality of this activity depends on the point at which the original firm's rights to control redistribution are exhausted under the law. The European Union has adopted a rigorous regime of regional exhaustion, which states that PI are impermissible from outside the community but first sale of a good within its territory, whether to distributors or final consumers, exhausts the original manufacturer's distribution rights. The U.S. policy of national exhaustion is essentially the same and redistribution rights are ended upon first sale anywhere within the country. Thus, parallel trade within the EU, and gray-market trade within the United States, are seen as a key form of integrating markets through legal arbitrage.

In fact there are circumstances in which consumer gains and market integra- 
tion can come into conflict. In particular, as discussed in the next section, EU case law rigorously defends the single market both by discouraging wholesale price discrimination across markets and upholding the ability of parallel trading companies to engage in commodity arbitrage. The United States is somewhat more forgiving of price differentiation but still limits its scope in order to preserve competition. To analyze these trade-offs we set out a model in which an original manufacturer has at its disposal just two instruments, the wholesale prices it can charge its independent distributors in two different markets. That price flexibility is central in managing a variety of inefficiencies that emerge in the presence of parallel trade. A policy requiring uniform wholesale charges reduces the number of instruments from two to one, making the problem more difficult for the manufacturer and potentially raising inefficiencies on the retail markets. Indeed, we find relevant market circumstances under which the uniform-price policy generates higher retail prices in both markets than would be the case with discriminatory prices, harming consumer welfare.

Thus, in this paper we analyze, within a model of integrated wholesale markets and vertical pricing, conditions under which the single-market objective is compatible with the goal of raising consumer welfare and conditions under which it is not. We are particularly interested in the issue of wholesale price discrimination and the effect it has on arbitrage between markets and on subsequent retail prices. The situation we have in mind involves a manufacturing firm with monopoly rights to distribute some good over which it owns intellectual property rights (IPR) in two markets. This firm sets non-linear prices, in the form of two-part tariffs, to its distributors in these countries. Because these prices are the control instruments available for the firm, their profit-maximizing levels likely are different across markets. Thus, the manufacturer has an incentive to discriminate in prices at the distributor level, a strategy that can reduce the volume of trade through parallel channels.

In our model we explore the impact of permitting parallel imports in the presence of wholesale price discrimination, on the one hand, and uniform pricing, on the other hand. Because manufacturing firms place goods on the market initially through vertical contracts with local distributors, it is important to study the implications of different competition policy regimes in this context. Both permission of PI and mandatory uniform prices are forms of competition policy but they have not before been studied in a framework involving vertical distribution and pricing. That is our objective in this paper and we find that there may be fundamental inconsistencies in the two regimes. We show that a 
policy requiring the manufacturing firm to charge nondiscriminatory prices can result in retail prices that are higher in all markets compared to an equilibrium with price discrimination. We also show that a policy of requiring uniform wholesale prices across locations would push retail prices toward convergence as transportation costs fall but this may not be optimal for welfare. More precisely, we demonstrate that, for a relevant range of trade costs, consumers in both markets can benefit jointly if policy permits the manufacturing firm to price discriminate among distributors.

The paper is organized as follows. In Section 2 we briefly overview relevant EU and U.S. case law. In Section 3 we present our model and in Section 4 we undertake theoretical analysis of the various policy regimes with one-way parallel trade. In Section 5 we extend the analysis to two-way trade. Concluding remarks are offered in Section 6.

\section{European Union and United States Case Law}

Parallel trade emerges from international price differences, which could exist at the wholesale level due to the strategic decisions of IPR holders. However, EU law prohibits certain types of price discrimination by a monopolist, specifically if the strategy puts one trading partner (e.g., a distributor or parallel-trading concern) at a competitive disadvantage vis-a-vis other trading partners. Article 82 of the EC Treaty states that price discrimination of this kind is abusive and illegal per se. Pricing that is harmful to the single market is considered to be a particularly serious infringement of Article 82 and prices charged to prevent or limit the scope for parallel trade are condemned.

The relevant European case law can be summarized in three principles (Whish, 2003). First, a monopolist cannot charge excessive prices or fees to impede parallel imports. This principle was established in the British Leyland (BL) case in 1984. Beginning in 1981 BL had refused to certify imported automobiles of its manufacture for use on British roads then later charged a fee of 150 pounds sterling for a certificate of conformity, where it charge 25 pounds sterling for a domestically purchased car. The European Commission found that BL, which was a dominant firm, abused its position both in refusing certification and charging differentially higher fees to parallel importing firms, with those fees being disproportionate to the value of the service provided. ${ }^{1}$ The

\footnotetext{
${ }^{1}$ See 84/379/EEC: Commission Decision of 2 July 1984 relating to a proceeding under Article 86 of the EEC Treaty (IV/30.615 - BL).
} 
prices impeded parallel trade and were, consequently, illegal.

Second, a monopolist can discriminate in prices across geographical markets only to a limited extent and the difference in prices must be "objectively" justified. This principle finds its roots in Article 82 of the EC Treaty, which states that an abuse of dominant position may consist in "directly or indirectly imposing unfair purchasing or selling prices to other companies." In United Brands the European Court of Justice (ECJ) ruled that, among other abuses of dominant position, the defendant acted illegally by charging different prices to distributors depending on the final destination of its product. ${ }^{2}$ In particular, UBC sold bananas in bulk to distributors in various member states at two central locations (Rotterdam and Bremerhaven), charging different prices to wholesalers from different countries. UBC argued that those prices were justified by being directly linked to final market prices for bananas in each country. The ECJ found that UBC was entitled to take local market conditions into account only to a limited extent, for the risks arising from local market conditions were borne by local distributors and retailers, whereas UBC was selling a homogeneous product in a centralized location. Thus, charging segmented prices based on geographical location was an abuse of pricing power and limited cross-border trade. Note that this case turned on prices being charged without sufficient relation to UBC's production cost. Thus,in the same case the ECJ held that evidence of abuse may be found by comparing price with production cost of a product. Because of the practical difficulty of computing production cost, the Court later determined in Tournier that such an assessment could be made by comparing the prices charged for the same product or service on other geographic markets, an item of direct relevance for PI. ${ }^{3}$ Similarly, in Tetra Pak II the Court found that the considerable price discrimination across Member States undertaken by the defendant, a dominant firm in materials for packaging liquid foods, was an abuse of position and incompatible with the single market. ${ }^{4}$ It could not be objectively attributed to market conditions for the relevant market was the entire EU and transport costs in the industry were low. Thus, the price discrimination was found to be a strategy to partition markets, violating Article 62 .

Third, it is illegal for a monopolist to practice price discrimination by granting rebates to distributors in a way that impedes growth of competition, as the

\footnotetext{
${ }^{2}$ Case 27/76, United Brands, ECR 207, 1978.

${ }^{3}$ Case 395/87, Tournier, ECR 1988.

${ }^{4}$ Case ECR I-5951, Tetra Pak II, November 1996.
} 
ECJ found in Irish Sugar. ${ }^{5}$ In particular, the discriminatory "border rebates" offered by the firm to customers located close to the Northern Ireland border were found to put those who did not quality for them at a competitive disadvantage. According to the ECJ, competition spillovers across borders are the essence of a common market and rebates that target competition from imports or exports are incompatible with Article 82. Similarly, in Michelin II the court found that a distributor-specific rebate scheme impeded access of other tire companies to the Netherlands market. ${ }^{6}$ Thus, rebates designed by a dominant firm to discourage cross-border purchases within the EU are illegal.

Turning to the United States, the legality of price discrimination is based on the Robinson-Patman Act of 1936 and subsequent guidelines issued by the Federal Trade Commission (FTC). In essence, this act bars setting price differences across customers if doing so constitutes an anti-competitive practice that injures competition. In subsequent interpretation, the courts have clarified that conditions of competition are paramount and that price discrimination that arises from legitimate cost differences or that otherwise does not interfere with other antitrust principles is acceptable. The Supreme Court has recognized that overly strict interpretations of Robinson-Patman could result in price uniformity and rigidity that itself may cause problems for competition. ${ }^{7}$

This stance implies that price differentiation is likely to run afoul of the courts primarily where it threatens to injure competition. In the principal case to date, a tobacco company was accused of violating the law by giving volume discounts for generic cigarettes to some wholesalers and not to others, where those discounts could be expected to reduce distributor costs in a predatory way and drive distributors of other firms out of business. ${ }^{8}$ While stipulating again that such price setting might be illegal, the Supreme Court found for the defendant because the plaintiff could not demonstrate a causal link to reduced competition and injury.

In a case similar to United Brands in the EU, the Supreme Court ruled in Texaco v. Hasbrouck that for an original firm to charge different wholesale (or retail) prices to its distributors (retail stores), it must be able to demonstrate with rigorous accounting that the price differential precisely reflects the addi-

\footnotetext{
${ }^{5}$ Case T-228/97, Irish Sugar plc, October 1999.

${ }^{6}$ Case T-201/01, Michelin II, September 2003.

${ }^{7}$ Great Atlantic and Pacific Tea Co. v FTC, 440 U.S. 69 No. 77-564 (1979).

${ }^{8}$ Brooke Group Ltd. v. Brown and Williamson Tobacco Corporation, 509 U.S. 209, No. 92-466 (1993).
} 
tional costs of selling to varying customers. ${ }^{9}$ In this case Texaco sold gasoline to two distributors at a price that was 3.7 to 6.0 cents per gallon lower than the "retail tank wagon" price at which it sold to 12 independent retailers in a particular locality. Texaco argued that it provided this "functional discount" to distributors to compensate them for the cost of building local distribution markets. The Supreme Court upheld lower-court verdicts against Texaco, finding that the defendant could not demonstrate a compelling cost-based reason for doing so and that competition had been injured.

On the basis of such findings it is fair to say that U.S. authorities uphold a policy barring price discrimination at the distributor level unless manufacturers can demonstrate a cost-based reason for it, but only if there is demonstrable injury to competition. The EU takes a more rigorous stance against such discrimination, though there remain exceptions (Geradin and Petit, 2007).

\section{A Theoretical Model of Cross-border Trade}

Our model builds on earlier work analyzing PI in a model of vertical price control. ${ }^{10}$ This approach was first set out by Maskus and Chen (2002) and Chen and Maskus (2005) and further developed by Ganslandt and Maskus (2007). They develop a simple model of vertical price control in which an original manufacturer sets wholesale prices to either one or two distributors, with the possibility of PI from one market to the other. As noted in those papers there are three essential efficiency trade-offs in this model. The manufacturer has to balance the losses from a pro-competitive price effect of parallel imports, the resource costs wasted in the activity of cross-border trade, and the double-markup problem in inducing a profit-maximizing retail price in the export market. Empirical evidence in Maskus and Chen (2002) and Ganslandt and Maskus (2003) points to vertical control problems as an important determinant of parallel trade. ${ }^{11}$

Perhaps the most closely related study is by Matsumura (2003). Using a spatial location model, he found that an upstream monopolist wishes to limit competition between two downstream duopolists by using exclusive territories.

\footnotetext{
${ }^{9}$ Texaco v. Hasbrouck, 496 U.S. 543, No. 87-2048 (1990).

${ }^{10}$ The other basic theory of PI considers simple arbitrage against retail prices. See Hilke (1988), Malueg and Schwartz (1994), and Richardson (2002). Ganslandt and Maskus (2004) find empirical evidence that PI in pharmaceuticals affects pricing power in Sweden.

${ }^{11}$ A study by National Economic Research Associates (1999) reported survey evidence of significant flows of parallel trade within the European Union in the early 1990s. While the report tended to focus on retail price differences, it pointed out that the bulk of parallel trade happens at the wholesale or distributor level.
} 
However, the existence of exclusive territories actually reduces final-product prices in local markets when distributors compete in quantities, because it induces lower wholesale prices in the first place. $^{12}$

In the model that follows we extend the vertical price control framework to consider the implications of competition-policy restrictions on pricing by the manufacturer. While we describe the model generally in terms of EU exhaustion policy permitting PI across national borders, the insights apply equally to graymarket trade across exclusive territories within the United States.

\subsection{Basic assumptions}

A manufacturer, $M$, sells its product in two markets, called $A$ and $B$. Firm $M$ sells its product through an independent exclusive distributor in each market. The demand in market $A$ is

$$
X=1-p_{A},
$$

and that in $B$ is

$$
Y=S\left(1-b p_{B}\right)
$$

It is assumed throughout the paper that demand in market $B$ is more priceelastic than demand in market $A$, i.e. $b>1$. It is also assumed that market $B$ is larger, i.e. $S \geq 1$. More precisely, market $B$ is sufficiently large to ensure that it is profitable for the manufacturing firm to serve both markets in equilibrium. Manufacturer $M$ has a constant marginal cost of production, which is $c$. The marginal cost of retailing in both countries is normalized to zero. Retail markets are segmented through much of the analysis, though we consider retail arbitrage late in the paper. ${ }^{13}$

Suppose that the manufacturing firm $M$ can offer the distributor in market $i(i=A, B)$ any contract in the form of $\left(w_{i}, T_{i}\right)$, where $w_{i}$ is the wholesale price and $T_{i}$ is a transfer payment (franchise fee) from the distributor to $M$. The

\footnotetext{
${ }^{12}$ Raff and Schmidt (2005) analyze the implications of exclusive territories used by firms in international trade. They concluded that trade liberalization may lead manufacturers to offset the loss of tariff barriers with contracts imposing exclusive territories, which may decrease competition and welfare.

${ }^{13}$ As argued in Ganslandt and Maskus (2007), this segmentation of consumer markets at the retail level can be motivated on several grounds. In some industries consumer arbitrage is illegal, while parallel trade at the wholesale level is permitted. This is the case with prescription drugs in the European Union for instance. In other industries, physical products and non-tradeable services are tied, causing effective market segmentation at the retail level. Local warranties bundled with capital goods and local plans bundled with cell phones are examples in this category. Finally, retail arbitrage can be prohibitively costly, while margins permit parallel trade at the wholesale level.
} 
manufacturing firm cannot prevent either distributor from selling the product also in the other market, either directly or through intermediaries, such as firms specialized in parallel trade. That is, we assume that either $M$ cannot legally limit the distributor's territory of sales, or it is too costly for $M$ to enforce any such constraint. The manufacturing firm can only control supply with wholesale prices. We rule out contracts that incorporate an agreement to limit the volume of parallel trade directly or indirectly. ${ }^{14}$

With this setup, suppose that the distributor incurs an additional constant marginal cost $t \geq 0$ in selling the good in the market where it is not located. For instance, $t$ could be the transaction cost or the transportation cost. Finally, assume that if the distributor sells in the market where it is not located, it competes with the local distributor in a Cournot fashion. Let the quantities sold in $A$ by the two distributors be $x_{A}$ and $x_{B}$, respectively, and the quantity sold in $B$ be $y_{A}$ and $y_{B}$. Subscripts refer to the identity of the distributor. A subgame-perfect Nash equilibrium is two pairs $\left(x_{A}, x_{B}\right)$ and $\left(y_{A}, y_{B}\right)$ that constitute Nash equilibria for any $\left(w_{i}, T_{i}\right)$ for $i=A, B$, together with an optimal choice of $\left(w_{i}, T_{i}\right)$ for $i=A, B$ by the manufacturing firm. Let $w$ denote the vector $\left(w_{A}, w_{B}\right)$ and $T$ denote the vector $\left(T_{A}, T_{B}\right)$.

Our main objective is to analyze how the manufacturing firm sets the wholesale prices and the transfer payments to maximize its profit. The manufacturing firm's profit is equal to total revenues in equilibrium minus real costs incurred. More precisely, the objective of the manufacturing firm is to maximize:

$$
\max _{w_{A}, w_{B}} X\left(p_{A}\right)\left(p_{A}-c\right)+Y\left(p_{B}\right)\left(p_{B}-c\right)-t\left(y_{A}+x_{B}\right) .
$$

where the first term on the right hand side is the total revenue (operating profit) in market $A$, the second term is the total revenue (operating profit) in market $B$ and the third term is the real cost of cross-border trade.

We initially derive the equilibrium of the model under two policy regimes. The first case is referred to as "discriminatory wholesale pricing". When discriminatory pricing is permitted, the manufacturing firm can set one wholesale price for each distributor and wholesale prices can potentially differ. The second case is referred to as "uniform wholesale pricing". In this case the manufacturing firm is required to charge the same wholesale price in both markets to ensure that neither distributor is put at a competitive disadvantage in relation to the other.

\footnotetext{
${ }^{14}$ As discussed by Ganslandt and Maskus (2007), such contracts would be illegal in the EU.
} 
Initially we make the assumption that only distributor $B$ can engage in crossborder trade. Consequently, distributor $A$ can sell only in its home market while distributor $B$ can choose to sell in both markets. There are several practical justifications for this assumption of one-way trade. First, if there are fixed costs (not explicitly modeled in this paper) and market $B$ is small while market $A$ is large, an asymmetry is possible, with products flowing from the small to the large country but not the other way around. Portugal and the United Kingdom within the European Union would exemplify this case. Second, there may be asymmetric product standards between the two countries. Third, the countries may vary in their legal treatment of PI, with international exhaustion the rule in $A$ and national exhaustion in B. Examples of the former are Australia and Hong Kong, which are open to PI in copyright goods, and examples of the latter are Japan and the United States, which are not. Still, this is a restrictive assumption and later we extend the analysis to permit two-way trade at the wholesale level. As we shall see this gives further insights but makes the analysis substantially more complex.

We assume that the marginal cost of production is sufficiently high to ensure that the manufacturing firm's optimal wholesale price in equilibrium is nonnegative ${ }^{15}$ and sufficiently low to ensure that there is positive demand in both markets at a price equal to the marginal cost of production, i.e.

$$
\frac{S b}{4(1+S b)}<c<\frac{1}{b}
$$

We analyze equilibria where the unit trade cost can be sufficiently low to potentially permit cross-border trade in equilibrium.

In the subsequent analysis, we compare the outcome with cross-border trade to an equilibrium that is segmented, either due to a prohibitive trade cost or contracts that effectively allocate an exclusive territory to each distributor. In the segmented equilibrium, the manufacturing firm can set wholesale prices and fixed fees in each market to avoid a double-markup problem and to induce optimal retail prices. In this case the wholesale prices are, accordingly, equal to the marginal cost of production, i.e. $w_{i}=c$, and the retail prices correspond to

\footnotetext{
${ }^{15}$ This is an important assumption for the results as we show in Ganslandt and Maskus (2007).
} 
the prices set by an integrated monopolist, which are

$$
\begin{aligned}
& p_{A}^{E T}=\frac{1+c}{2}, \\
& p_{B}^{E T}=\frac{1+b c}{2 b} .
\end{aligned}
$$

We shall refer to this case as our benchmark equilibrium. In the segmented equilibrium, the retail price in market $A$ exceeds the retail price in market $B$, reflecting the less price-elastic demand in the former market. It follows that markets are naturally segmented for a sufficiently high $t$, i.e.

$$
t \geq \frac{1-c}{2}
$$

We label trade costs in this high range "prohibitive".

\section{Cross-border trade}

\subsection{The sub-game retail equilibrium}

The next task is to analyze the effects of cross-border trade. Before we analyze the manufacturing firm's optimal behavior it is useful to derive the sub-game retail equilibrium. A common feature of the three cases we shall analyze below is that market segmentation is imperfect. The manufacturing firm can neither

directly nor indirectly impose exclusive territories. Recall that both distributors can sell in market $A$, while only the local distributor can sell in market $B$.

More precisely, in the retail sub-game the manufacturing firm has offered two contracts, $\left\{T_{A}, w_{A}\right\}$ and $\left\{T_{B}, w_{B}\right\}$, that have been accepted by the distributors. The distributors non-cooperatively set quantities in a Cournot-fashion in market $A$ and the local distributor chooses a profit-maximizing quantity in market $B$. The sub-game equilibrium in market $A$ is consequently given by the well-known Cournot output

$$
\begin{aligned}
& x_{A}=\frac{1-2 w_{A}+w_{B}+t}{3} \\
& x_{B}=\frac{1+w_{A}-2 w_{B}-2 t}{3}
\end{aligned}
$$

subject to the condition that wholesale prices are such that equilibrium quantities are non-negative. Similarly, the sub-game equilibrium quantity in market 
$\mathrm{B}$ is given by the monopoly solution

$$
y_{B}=S\left(\frac{1-b w_{B}}{2}\right) .
$$

The corresponding retail price in markets $A$ and $B$ are, respectively,

$$
\begin{aligned}
& p_{A}=\frac{1+w_{A}+w_{B}+t}{3}, \\
& p_{B}=\frac{1+b w_{B}}{2 b} .
\end{aligned}
$$

For a sufficiently high trade cost, above a threshold denoted $\widetilde{t}$, parallel trade is unprofitable in equilibrium. In other words, the equilibrium is arbitragefree. More precisely, cross-border trade is blocked if the manufacturing firm sets wholesale prices that satisfy the no-arbitrage condition

$$
\frac{1+w_{A}}{2} \leq w_{B}+t
$$

and the sub-game retail equilibrium prices are

$$
\begin{aligned}
& p_{A}=\frac{1+w_{A}}{2}, \\
& p_{B}=\frac{1+b w_{B}}{2 b} .
\end{aligned}
$$

This is a sufficient characterization of the sub-game equilibrium for our purposes. We can now proceed to the analysis of the manufacturing firm's behavior under different institutional assumptions. First, we analyze wholesale price discrimination under the assumption that the producer is allowed to set one wholesale price for each distributor but is not permitted to restrict cross-border trade through any direct contractual means. Second, we investigate the effects of uniform pricing, based on the policy presumption that price discrimination that puts one trading partner at a competitive disadvantage is illegal. Thus, the producer must set one uniform wholesale price for both distributors.

\subsection{Discriminatory Wholesale Pricing (D)}

We start our analysis with wholesale price discrimination. For this purpose we assume that the manufacturing firm can set one price for each distributor. In this case the manufacturing firm has two instruments with which to solve three 
problems: inducing the profit-maximizing retail price in each market and ensuring an efficient global distribution by minimizing cross-border parallel trade, which wastes resources. Since the producer has too few instruments we shall expect inefficiencies and a sub-optimal outcome compared to exclusive territories.

The manufacturing firm set wholesale prices to maximize total profits

$$
\max _{w_{A}, w_{B}} X(w)\left(p_{A}(w)-c\right)+Y(w)\left(p_{B}(w)-c\right)-t x_{B}(w),
$$

where the last term on the right hand side is the resources used in trade from market $B$ to $A$. Next, we find the equilibrium under two possible price-setting strategies: wholesale prices that permit PI and wholesale prices that block PI (we shall refer to the latter as arbitrage-free prices). We derive the optimal wholesale prices and compare the producer's profit in both of these cases to find the more profitable strategy.

The optimal wholesale prices that permit cross-border trade can be found by solving the following two first-order conditions with respect to $w_{A}$ and $w_{B}$

$$
\begin{aligned}
\frac{1-2 w_{A}-2 w_{B}-2 t+3 c}{9}-\frac{t}{3} & =0, \\
\frac{1-2 w_{A}-2 w_{B}-2 t+3 c}{9}+\frac{2 t}{3}-\frac{S b\left(w_{B}-c\right)}{2} & =0,
\end{aligned}
$$

The first term on the left hand side of both conditions is the pro-competitive effect in market $A$ (which we term the horizontal externality between the competing distributors because it reduces the manufacturer's profit). The second terms in both equations are the effects of costly cross-border trade (which we term inefficient distribution). The third term on the left hand side of the second condition, with respect to $w_{B}$, is the double-markup problem in market $B$ (which we term the vertical externality between the distributor and the manufacturing firm).

Note that for $t=0$ the second terms are zero and the total number of problems for the manufacturing firm is two, the same as the number of instruments available. In this case the wholesale prices are perfect substitutes for inducing the profit-maximizing monopoly retail price in market $A$. The optimal retail price in market $B$ must, however, be induced solely with the wholesale price to the local distributor there. The unique wholesale price that solves the vertical externality equals the marginal cost of production. The manufacturing firm can 
thus obtain the same profit as a vertically integrated monopolist by combining the two wholesale prices to solve both the horizontal and vertical problems in this case.

If the trade cost is positive, however, there is an additional distortion that prohibits the manufacturing firm from obtaining the first-best outcome in retail markets. The manufacturing firm must therefore balance the trade-offs among the horizontal externality in market $A$, the inefficiency in distribution and the vertical externality in market $B$.

The severity of the problem with inefficient parallel trade increases in the trade cost. For a sufficiently high trade cost, above a threshold denoted $\widetilde{t}^{D}$ (derived below), it is profitable for the manufacturing firm to set arbitrage-free wholesale prices. These are prices that make cross-border trade unprofitable in equilibrium. Accordingly, to block PI the manufacturing firm sets wholesale prices that satisfy the no-arbitrage condition

$$
\frac{1+w_{A}}{2} \leq w_{B}+t
$$

The producer's profit can be differentiated subject to this condition. We obtain the following first-order condition for wholesale prices that block parallel trade

$$
\left(1+c-2 w_{B}-2 t\right)-\frac{S b\left(w_{B}-c\right)}{2}=0,
$$

where the first term on the left hand side is the horizontal externality in market $A$ and the second term is the vertical problem in market $B$. The first-order condition gives the profit-maximizing wholesale price in $B$ while the wholesale price in $A$ can be obtained from the no-arbitrage condition.

If we solve for the vectors of wholesale prices that permit and block PI we obtain the following result:

Proposition 1 Assume that the trade cost is non-prohibitive and the producer can set one wholesale price for each distributor. Then the equilibrium wholesale 
prices are

$$
\begin{aligned}
w_{A}^{D} & =\frac{1+c}{2}-\frac{4+5 S b}{2 S b} t \text { and } \\
w_{B}^{D} & =c+\frac{2 t}{S b} \text { for } t \leq \widetilde{t}^{D}, \\
w_{A}^{D} & =\frac{2 c(2+S b)+(2 t-1) S b}{4+S b} \text { and } \\
w_{B}^{D} & =\frac{2+2 c+S c b-4 t}{4+S b} \text { for } t>\widetilde{t}^{D},
\end{aligned}
$$

and the equilibrium is unique.

The equilibrium volume of cross-border trade can be obtained by inserting the equilibrium wholesale prices for low trade costs $\left(t \leq \widetilde{t}^{D}\right)$, given by $(21)$, in equation (9). It follows that the volume of trade for $t \leq \widetilde{t}^{D}$ is

$$
x_{B}^{D}=\frac{1-c}{2}-\frac{4+3 S b}{2 S b} t
$$

which decreases in the unit trade cost, $t$. Parallel trade consequently occurs in equilibrium for low trade costs, while the equilibrium is arbitrage-free for higher trade costs. The threshold for arbitrage-free prices is

$$
\widetilde{t}^{D}=\frac{(1-c) S b}{4+3 S b}
$$

which is strictly positive and below the prohibitive trade cost.

A closer look at the equilibrium reveals that the wholesale price in market $A$ first falls as trade cost increases in the low range $\left(t \leq \widetilde{t}^{D}\right)$, then rises as the unit trade cost goes beyond the threshold level. In contrast, the wholesale price in market $B$ first increases and then decreases. The result for the low-cost range $\left(t \leq \widetilde{t}^{D}\right)$ is intuitive since the manufacturing firm would reduce the price in $A$ and raise the price in $B$ to moderate the negative effect of costly cross-border trade. This incentive becomes stronger as trade costs rise. Indeed, note from (21) that for a trade cost,

$$
t>\widetilde{t}^{S}=\frac{(1-c) S b}{4+5 S b},
$$

where superscript $\mathrm{S}$ refers to "subsidy", the manufacturing firm prefers to set a wholesale price in market $A$, i.e. $w_{A}$, that is below marginal cost. This would imply a decision to subsidize the distributor in market $A$, which would 
be profitable for the manufacturing firm because it makes that distributor more aggressive and reduces the volume of inefficient trade.

\subsection{Uniform Wholesale Pricing (U)}

The analysis in the previous section shows that the manufacturing firm has a strategic motive to put one distributor at a competitive disadvantage and reduce the volume of PI. In this section we shall derive the equilibrium under the assumption that the government forces the producer to charge a uniform

wholesale price. As we noted in the introduction, the government might enforce a competition law under which wholesale price discrimination is illegal (cf. Article 82 in the EC Treaty or the Robinson-Patman Act). The manufacturing firm must therefore set the same wholesale price, $w_{A B}$, for both distributors.

As in the previous section we consider the possibility that the manufacturing firm could set either a wholesale price that permits cross-border trade or a wholesale prices that deters it. In an equilibrium with parallel trade the wholesale price must solve this first-order condition

$$
\frac{2-8 w-4 t+6 c}{9}+\frac{t}{3}-\frac{S b(w-c)}{2}=0
$$

where the first term on the left hand side reflects the pro-competitive effect of trade in market $A$ (the horizontal externality), the second term is the effect of wasteful PI (the inefficiency in distribution) and the third term is the potential double-markup problem in market $B$ (the vertical externality).

For sufficiently high trade costs, above a threshold $\widetilde{t}^{U}$ (derived below), it is optimal to set an arbitrage-free wholesale price. In this case, the following condition must hold

$$
w \geq 1-2 t
$$

This constraint is enough to ensure that the wholesale price is arbitrage-free and the distributor in $B$ does not engage in PI. The equilibrium is presented in the following proposition:

Proposition 2 Assume that the trade cost is non-prohibitive and the manufacturing firm sets a uniform wholesale price, i.e. $w_{A}=w_{B}$. Then the equilibrium 
wholesale price is

$$
\begin{aligned}
& w_{A}^{U}=w_{B}^{U}=\frac{4+9 S c b+12 c-2 t}{9 S b+16} \text { for } t \leq \widetilde{t}^{U}, \\
& w_{A}^{U}=w_{B}^{U}=1-2 t \text { for } t>\widetilde{t}^{U},
\end{aligned}
$$

and the equilibrium is unique.

Here, the wholesale price is a continuous decreasing function in the unit trade cost and the volume of parallel trade for $t$ below the new threshold is

$$
x_{B}^{U}=\frac{(3 S b+4)(1-c)-(10+6 S b) t}{9 S b+16} .
$$

The wholesale price is arbitrage-free for any trade cost greater than this threshold

$$
\widetilde{t}^{U}=\frac{(1-c)(4+3 S b)}{10+6 S b} .
$$

Further, note that $\widetilde{t}^{U}>\widetilde{t}^{D}$, which shows that PI exist in equilibrium for higher trade costs than with discriminatory wholesale prices. The intuition for this is that it is relatively more expensive for the producer to use the uniform wholesale price to reduce the volume of parallel trade. If the manufacturing firm is required to set a uniform price and it increases that price for intermediate and high trade costs, the result is a double-markup problem in both retail markets. The vertical control problem is consequently more difficult to solve with a uniform price than with a discriminatory price.

\section{$5 \quad$ Welfare}

Competition policy has as its objective to enhance welfare and protect consumer interests. This section is accordingly devoted to an analysis of consumer surplus and welfare under discriminatory and uniform pricing. For this purpose we define welfare as the sum of aggregated consumer surplus in both markets plus the manufacturing firm's profit. Consumer surplus is uniquely determined by the retail prices. For a given trade cost and a given marginal cost of production, the manufacturing firm's profit is uniquely determined by retail prices and the volume of cross-border trade. From a welfare perspective the most interesting variables are, consequently, the retail prices and the level of parallel imports.

Two conclusions highlight our results. First, for trade costs above a thresh- 
old $\widehat{t}$ (computed below), the policy of requiring a uniform wholesale price is Pareto-dominated by market segmentation. The reason is that uniform wholesale prices generate higher retail prices in both markets while reducing firm profits. This suggests that the policy of not permitting price discrimination, designed to safeguard wholesale competition, easily could have the unintended consequence of reducing economic well-being. However, at low trade costs, below the threshold $t^{\prime}$ (computed below), the uniform-price policy can generate gains in consumer welfare. Thus, it seems that uniform pricing and policies taken to reduce transactions costs, such as harmonized product standards, could be complementary.

The welfare rankings between uniform and discriminatory wholesale pricing are more complex. We describe here the interesting and relevant case where markets differ noticeably in demand elasticity (e.g., a high value for $b$ ), which ensures that the retail price in market $B$ is below the retail price in market $A$. We consequently assume that $b$ satisfies the sufficient condition

$$
b \geq \frac{2}{1+c} .
$$

This situation could characterize market conditions when low-income Eastern European economies join the high-income existing EU members and parallel trade is unrestricted. In this case we show that the restraint of a uniform wholesale price diminishes joint consumer welfare for a unit trade cost above the threshold $t^{\prime}$.

To establish these results we first derive the retail prices in the discriminatory pricing equilibrium. We insert the equilibrium wholesale prices (21) and (23) in equations (11) and (12) to obtain

$$
\begin{aligned}
p_{A}^{D} & =\frac{1+c-t}{2} \text { and } \\
p_{B}^{D} & =\frac{S+S c b+2 t}{2 b S} \text { for } t \leq \widetilde{t}^{D}, \\
p_{A}^{D} & =\frac{2+t S b+2 c+S c b}{4+S b} \text { and } \\
p_{B}^{D} & =\frac{1}{2 b}+\frac{2+2 c+S c b-4 t}{2(4+S b)} \text { for } t>\widetilde{t}^{D},
\end{aligned}
$$

which are continuous functions in the unit trade cost with kinks at the critical threshold for arbitrage-free prices, $\widetilde{t}^{D}$. For illustrative purposes we have plotted retail prices as functions of the unit trade cost in Figure 1. We also show the 
volume of parallel trade, $x_{B}^{D}$.

Note that as the unit trade cost falls from the level supporting exclusive territories (ET), the gap between retail prices narrows for this intermediate range of trade costs due to the manufacturing firm's incentive to block wasteful cross-border trade. Accordingly, the threat of parallel trade results in retail price convergence to some extent. However, this convergence is not due to a pro-competitive effect but arises from the manufacturing firm's inability to fully manage the vertical control problem. Once the trade cost falls below the threshold we find that retail prices actually move apart, a result consistent with that in Ganslandt and Maskus (2007). This stems from the manufacturer's incentive to establish different wholesale prices (with that in $A$ rising and that in $B$ falling as $t$ declines) in order to minimize the horizontal externality in the import market, even as the volume of PI goes up.

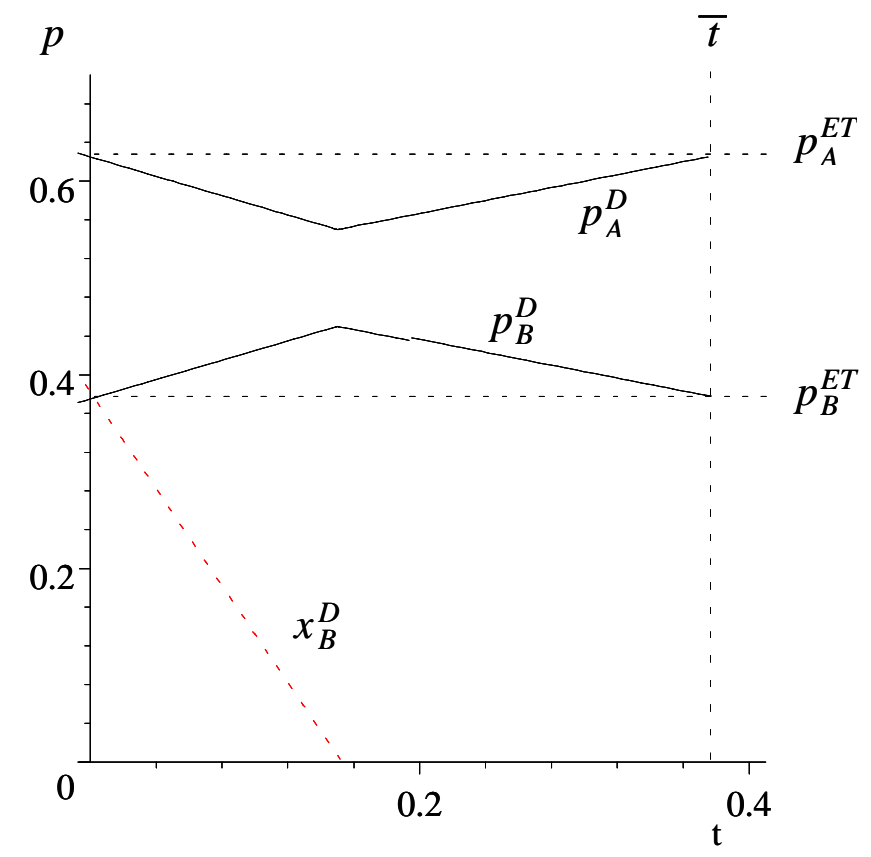

Figure 1: Retail prices in the discriminatory wholesale pricing equilibrium $(S=$ $1, b=2, c=1 / 4)$

Next, we derive the retail prices in the uniform pricing equilibrium. We insert the optimal wholesale price given by (30) and (31) in the sub-game equilibrium 
(11) and (12) to obtain the retail prices

$$
\begin{aligned}
p_{A}^{U} & =\frac{1+t}{3}+\frac{2}{3}\left(\frac{4+9 S c b+12 c-2 t}{9 S b+16}\right) \text { and } \\
p_{B}^{U} & =\frac{1}{2 b}+\frac{1}{2}\left(\frac{4+9 S c b+12 c-2 t}{9 S b+16}\right) \text { for } t \leq \widetilde{t}^{U}, \\
p_{A}^{U} & =1-t \text { and } \\
p_{B}^{U} & =\frac{1}{2 b}+\frac{1}{2}-t \text { for } t>\widetilde{t}^{U},
\end{aligned}
$$

with kinks at the threshold for the arbitrage-free price in this case. Retail prices in both markets are above the segmented levels, i.e. $p_{A}^{U} \geq p_{A}^{E T}$ and $p_{B}^{U} \geq p_{B}^{E T}$, if the trade cost is above the critical threshold

$$
\widehat{t}=\frac{3 S b(1-c)}{6 S b+8},
$$

which is below the threshold for arbitrage-free prices. The retail prices as functions of the unit trade cost under uniform wholesale pricing are illustrated in Figure 2.

There are two interesting features of this equilibrium. First, a uniform wholesale price results in retail prices above the segmented price in both markets for intermediate and high trade costs (and in market $B$ throughout the range). It is optimal for the manufacturing firm to set a wholesale price that results in a double-markup problem in both markets in order to minimize the waste of resources in PI. Second, the volume of cross-border trade with a uniform wholesale price is a decreasing function in $t$. The gap between retail prices in markets $A$ and $B$ is relatively narrow for low trade costs and relatively wide for higher trade costs. A policy that requires the manufacturing firm to set non-discriminatory wholesale prices will thus have a pro-competitive effect in market $A$ for low trade costs and the effect is some degree of price integration.

The aggregated consumer surplus is

$$
C S=\left[\left(X-\frac{X^{2}}{2}\right)-p_{A} X\right]+\left[\frac{1}{b}\left(Y-\frac{Y^{2}}{2 S}\right)-p_{B} Y\right]
$$

where the first term is consumer surplus in $A$ and the second term is consumer surplus in $B$. We insert the demand functions in markets $A$ and $B$ to get consumer surplus as a function of the retail prices: 


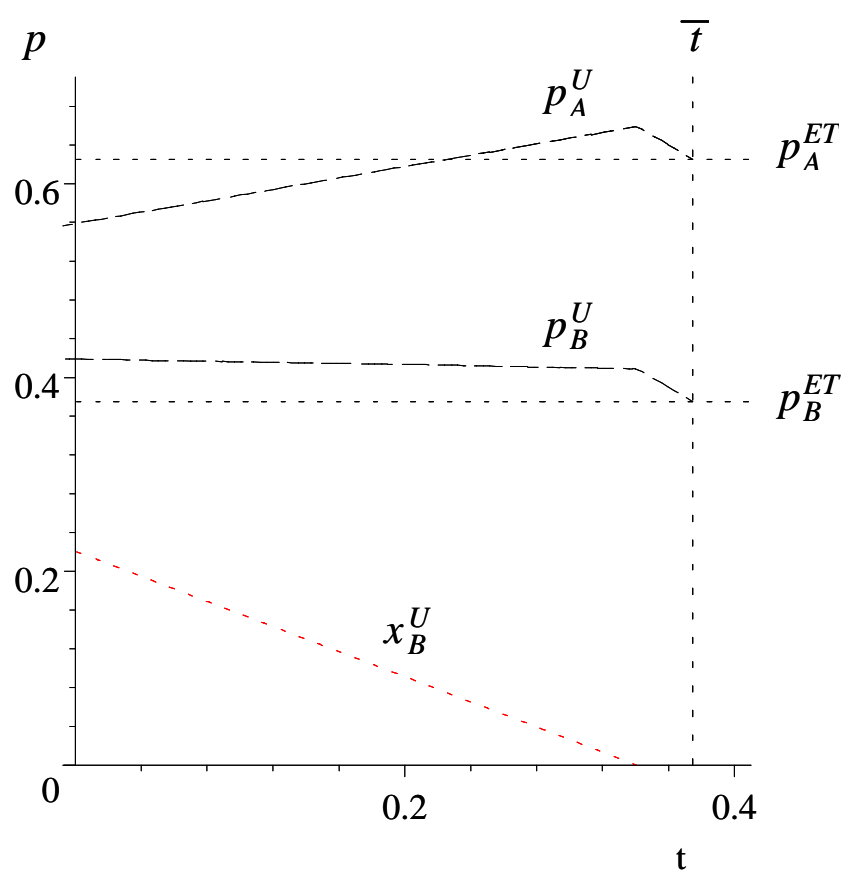

Figure 2: Retail prices in the uniform wholesale pricing equilibrium $(S=1, b=$ $2, c=1 / 4)$

$$
C S(p)=\frac{1}{2}\left(1-p_{A}\right)^{2}+\frac{S}{2 b}\left(1-b p_{B}\right)^{2}
$$

which is continuous, concave and decreasing in both $p_{A}$ and $p_{B}$. The aggregated consumer surplus values under price discrimination and under a uniform wholesale price are summarized in Table 1. 
Table 1: Total consumer surplus, CS

Discriminatory wholesale pricing, $t \leq \widetilde{t}^{D}$ :

$\frac{1}{2}\left(1-\left(\frac{1}{2}+\frac{1}{2} c-\frac{1}{2} t\right)\right)^{2}+\frac{S}{2 b}\left(1-b\left(\frac{1}{2 b} \frac{S+S c b+2 t}{S}\right)\right)^{2}$

Discriminatory wholesale pricing, $t>\widetilde{t}^{D}$ :

$\frac{1}{2}\left(1-\left(\frac{2+S b t+2 c+S c b}{4+S b}\right)\right)^{2}+\frac{S}{2 b}\left(1-b\left(\frac{4+S b+2 b+2 c b+S c b^{2}-4 b t}{2(4+S b) b}\right)\right)^{2}$

Uniform wholesale pricing, $t \leq \widetilde{t}^{U}$ :

$\frac{1}{2}\left(1-\left(\frac{3 S b+8+6 S c b+8 c+4 t+3 S b t}{9 S b+16}\right)\right)^{2}+\frac{S}{2 b}\left(1-b\left(\frac{1}{2} \frac{9 S b+16+4 b+9 S c b^{2}+12 c b-2 b t}{(9 S b+16) b}\right)\right)^{2}$

Uniform wholesale pricing, $t>\widetilde{t}^{U}$ :

$\frac{1}{2}(1-(1-t))^{2}+\frac{S}{2 b}\left(1-b\left(\frac{1+b}{2 b}-t\right)\right)^{2}$

Total consumer surplus functions under discriminatory and uniform wholesale pricing are illustrated in Figure 3. The aggregated consumer surplus under discriminatory pricing has its maximum for intermediate trade costs, where the retail price gap is relatively narrow. The allocation in the retail markets is accordingly relatively efficient for the intermediate range of trade costs. The allocative inefficiency increases and consumer surplus decreases in the retail price gap. The minimum consumer surplus under discriminatory wholesale pricing accordingly occurs for zero and prohibitive trade costs, when the equilibrium retail prices are identical to the retail prices in a segmented equilibrium.

In the uniform wholesale pricing equilibrium, the aggregated consumer surplus has its maximum when the trade cost is zero due to the price-integrating effect of cross-border trade in that case. Aggregated consumer surplus has its minimum at the threshold for an arbitrage-free wholesale price, which is close to the prohibitive trade cost. At this point the double-markup problems in both markets are most severe and the resulting retail prices are above the prices in a segmented equilibrium, while the retail price gap is just as wide as in the segmented equilibrium. There are consequently no offsetting benefits of price integration.

We see that wholesale price discrimination dominates the uniform wholesale price for intermediate and high trade costs $\left(t \geq t^{\prime}\right)$, while the uniform price 


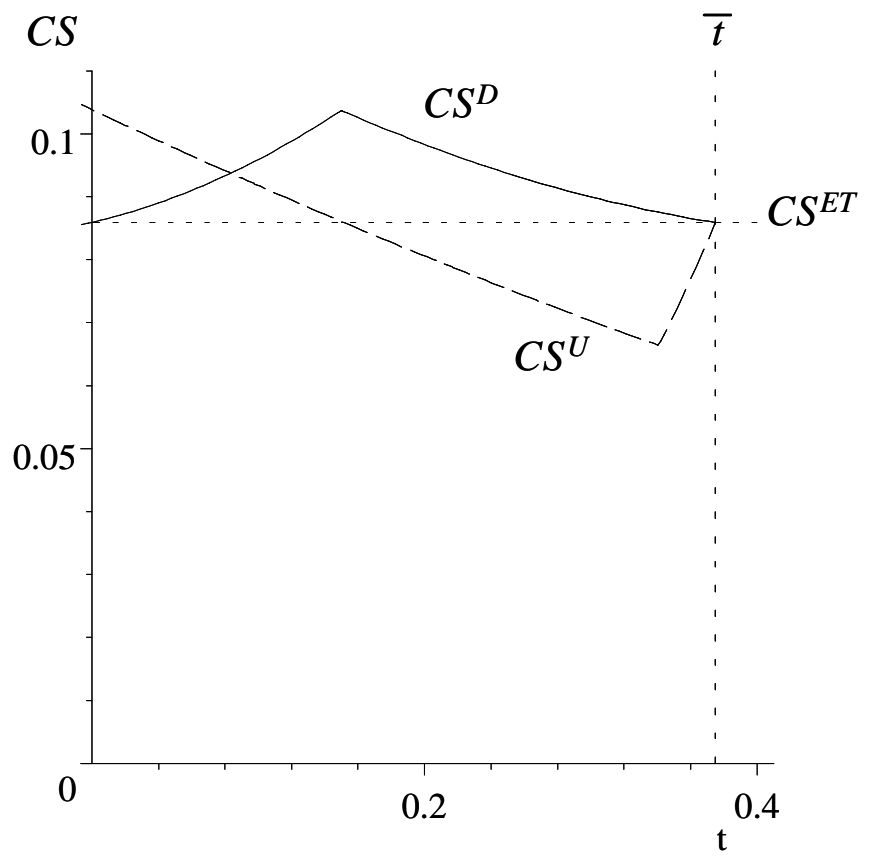

Figure 3: Total consumer surplus with discriminatory and uniform wholesale pricing $(S=1, b=2, c=1 / 4)$

dominates for low trade costs $\left(t<t^{\prime}\right)$. The critical threshold is

$$
t^{\prime}=\frac{S b(1-c)}{8+5 S b}
$$

Consumers are consequently better off as a group with non-discriminatory prices if the unit trade cost is low. The intuition for this is straightforward. Crossborder trade has both a pro-competitive and price-integrating effect for low trade costs. The narrow gap between retail prices in the two markets has a positive effect on total consumer surplus due to a relatively moderate allocative distortion compared to that under discriminatory prices.

Having considered consumer welfare we now proceed to compute the equilibrium profit for the manufacturing firm. We insert wholesale prices in equation (16) to obtain the profit under discriminatory and uniform wholesale pricing. The manufacturing firm's profit under price discrimination and a uniform wholesale price is summarized in Table 2 . 
Table 2: The manufacturing firm's profit

Discriminatory wholesale pricing, $t \leq \widetilde{t}^{D}$ :

$\frac{S}{4 b}+\frac{1+b S c^{2}-2 S c-2 c+c^{2}}{4}+t\left(\frac{5 t b S+4 t-2 b S+2 S c b}{4 b S}\right)$

Discriminatory wholesale pricing, $t>\widetilde{t}^{D}$ :

$\frac{b S t(1-c-t)}{4+b S}+\frac{\left(1-2 c b+c^{2} b^{2}\right) S}{4 b}+\frac{(1-c)^{2}}{4+b S}$

Uniform wholesale pricing, $t \leq \widetilde{t}^{U}$ :

$\frac{S(1-2 b c)}{4 b}+\frac{16+16 c^{2}+8 b S-16 S c b+24 S c^{2} b-32 c+9 c^{2} b^{2} S^{2}}{4(9 b S+16)}+t\left(\frac{5 t b S+9 t-4+4 c-2 b S+2 S c b}{9 b S+16}\right)$

Uniform wholesale pricing, $t>\widetilde{t}^{U}$ :

$(1-c-t) t+\frac{S(1+b-2 b t-2 c b)(1-b+2 b t)}{4 b}$

Profits under discriminatory and uniform wholesale pricing are illustrated in Figure 4. The profit of the manufacturing firm is higher under discriminatory pricing than uniform pricing for obvious reasons. The firm has one more instrument to solve the three problems it faces, and it can accordingly set prices that result in less parallel trade and retail prices closer to the optimal level compared to the constraint it operates under with the uniform wholesale pricing equilibrium.

The firm's profit is a U-shaped function in the trade cost under both discriminatory and uniform wholesale pricing. The profit function under discriminatory wholesale pricing has its minimum at a relatively low trade cost, i.e.

$$
t=\frac{b S(1-c)}{5 b S+4}
$$

At this point the total resources used in cross-border trade are significant and the inefficiency in distribution is substantial. Under uniform wholesale pricing this point is at a higher trade cost, i.e.

$$
t=\frac{(1-c)(2+b S)}{5 b S+9}
$$

and the minimum for this profit function is accordingly at an intermediate trade cost. 


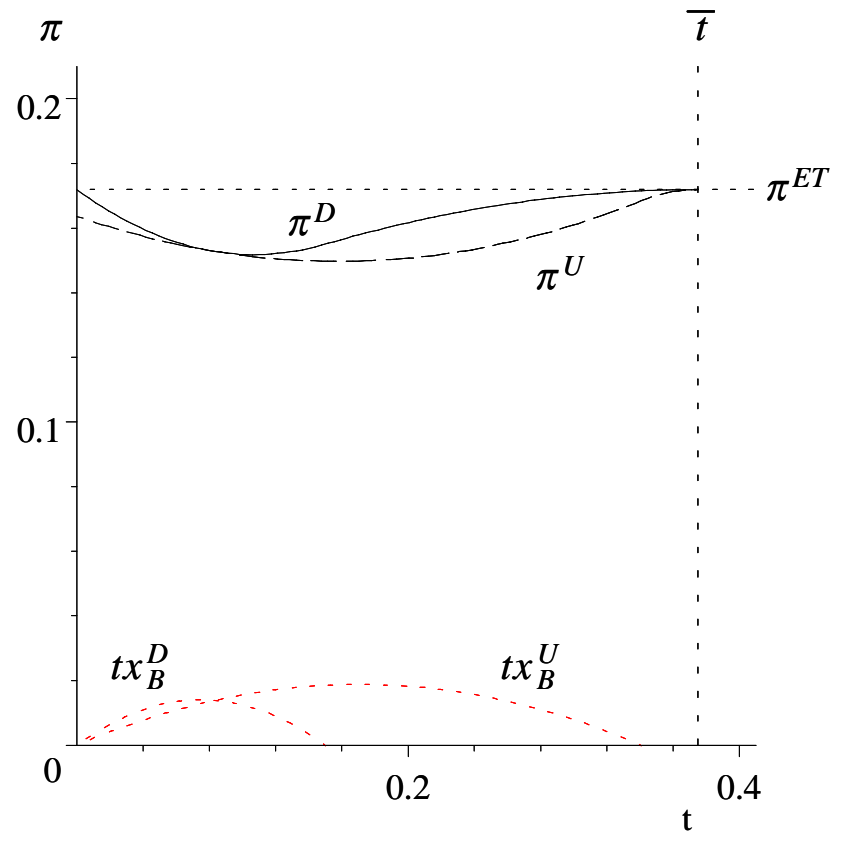

Figure 4: The manufacturing firm's profit with discriminatory and uniform wholesale pricing $(S=1, b=2, c=1 / 4)$

Finally, total welfare is the sum of consumer surplus and the manufacturing firm's profit. It is illustrated in Figure 5. It is evident that the requirement not to discriminate in wholesale prices generates higher welfare only at low trade costs.

\section{$6 \quad$ Extensions}

The analysis above is based on two important assumptions. One was that, under the discriminatory wholesale pricing regime, the marginal cost of production is sufficiently high to permit the manufacturing firm to subsidize the distributor in market $A$ with a wholesale price below the marginal cost of production for some trade costs. Another was that retail markets are segmented. We assumed that the distributor (or his agent) is prohibited from buying the good in one retail market and shipping it to the other market. In this section we extend our analysis by relaxing both these assumptions. 


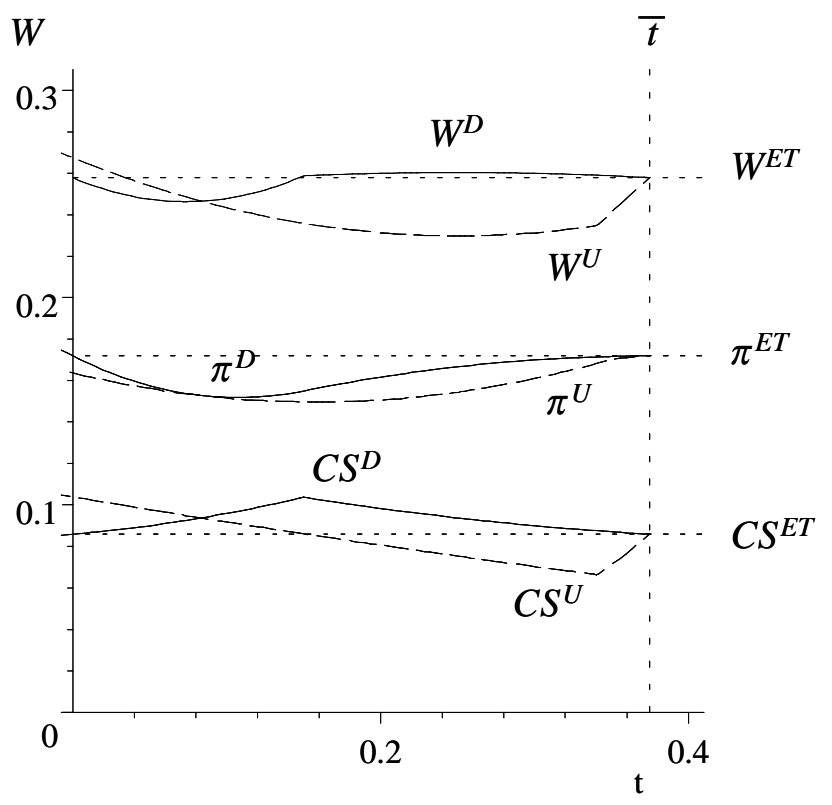

Figure 5: Welfare with discriminatory and uniform wholesale pricing $(S=1, b=$ $2, c=1 / 4)$

\subsection{Wholesale Pricing At or Above Marginal Cost (C)}

We noted above that for some trade costs the manufacturing firm has a strategic incentive to subsidize the local distributor in the import market in order to make it more aggressive and take market share from the importing distributor. This subsidization involves a wholesale price that is below the marginal cost of production.

Now consider the possibility that the manufacturing firm cannot subsidize the distributor in market $A$. For instance, the competition authorities may impose a restriction that the manufacturing firm must charge a wholesale price that covers its marginal cost of production or the marginal cost of production may be close to zero, thus restricting the scope for subsidization. This might be called a policy of "non-exclusionary" pricing for it precludes the manufacturer from subsidizing one distributor to the exclusion of the other.

The optimal wholesale price in market $B$ that permits parallel trade can be found by solving the first-order condition subject to the binding restriction 


$$
w_{A}=c \text {, i.e. } \quad \frac{1+c-2 w_{B}-2 t}{9}+\frac{2 t}{3}-\frac{S b\left(w_{B}-c\right)}{2}=0
$$

where the wholesale price in $A$ is simply replaced by the marginal cost of production. Since the binding restriction on the wholesale price in market $A$ pushes that price above the optimal level, the manufacturing firm must use the wholesale price in market $B$ to reduce the volume of cross-border trade. This forces the manufacturing firm to charge a higher price to the local distributor in $B$, which exacerbates the double-markup problem there.

For sufficiently high trade costs, above the critical threshold $\widetilde{t}^{C}$, it is optimal for the manufacturing firm to block cross-border trade. Arbitrage-free wholesale prices must satisfy the following condition

$$
w_{B} \geq \frac{1+c-2 t}{2}
$$

and we have the following result:

Proposition 3 Assume that the trade cost is non-prohibitive and wholesale prices must be above or equal to the marginal cost of production. Then the equilibrium wholesale prices are

$$
\begin{aligned}
& w_{A}^{C}=\max \left(\frac{1+c}{2}-\frac{4+5 S b}{2 S b} t, c\right) \\
& w_{B}^{C}=\min \left(c+\frac{2 t}{S b}, \frac{2+2 c+8 t+9 S c b}{4+9 S b}, \frac{1+c-2 t}{2}\right)
\end{aligned}
$$

and the equilibrium is unique.

The assumption that wholesale prices must be non-exclusionary is binding for intermediate and high trade costs, $t \geq \widetilde{t^{S}}$, given by (27). In the intermediate range the volume of parallel trade is

$$
x_{B}^{C}=\frac{3 S b(1-c)-(8+6 S b) t}{4+9 S b}
$$

which is strictly more than the volume of such trade when the manufacturing firm sets a subsidized price to the distributor in market $A$. This is not surprising since the manufacturing firm essentially lost one control instrument $\left(w_{A}\right)$. Parallel trade consequently occurs in equilibrium for a wider range of trade costs. 
The threshold for arbitrage-free prices is now

$$
\widetilde{t}^{C}=\frac{3}{2} \frac{(1-c) S b}{4+3 S b}
$$

which is strictly higher than the threshold with price discrimination $\left(\widetilde{t}^{D}\right)$. The effect of a policy that bans subsidies by precluding wholesale prices below marginal cost is, consequently, an increased volume of PI for a wider range of trade costs.

We insert the equilibrium wholesale prices (51) and (52) into the sub-game equilibrium (11) and (12) to obtain the retail prices as functions of the unit trade cost and the volume of cross-border trade, which are illustrated in Figure 6 .

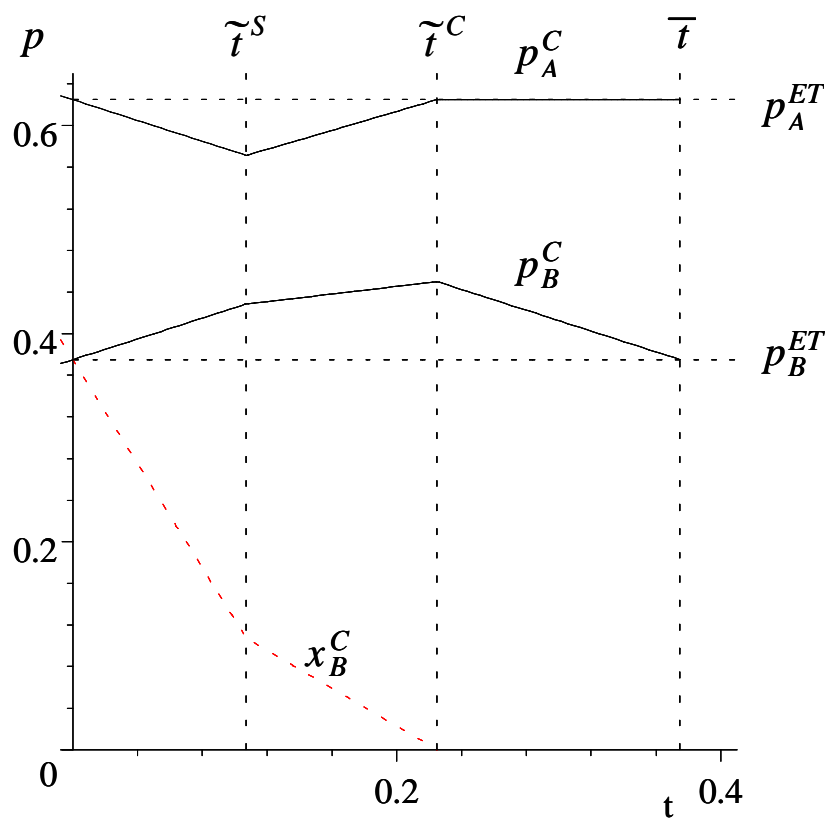

Figure 6: Retail prices in an equilibrium with wholesale prices at or above marginal cost $(S=1, b=2, c=1 / 4)$

For high trade costs, i.e. $t>\widetilde{t}^{C}$, wholesale prices that are at or above marginal cost are Pareto-dominated by discriminatory wholesale pricing. Consumers in market $A$, consumers in market $B$ and the manufacturing firm are 
all worse off. This result stems from the manufacturing firm's market power. A restriction on prices in a market with imperfect competition can generate significant distortions that make the equilibrium substantially less efficient. In our case the manufacturing firm must use the wholesale price in $B$ to reduce the scope for costly cross-border trade. The effect is that the retail prices increase in both markets. Consumption accordingly moves away from what would be the first-best solution for the manufacturing firm, i.e. the segmented equilibrium, and both consumers and the manufacturing firm lose as a result.

\subsection{Retail arbitrage}

We initially assumed that retail markets are segmented. While we think this is a relevant assumption in many cases, readers may wonder about the implications of retail arbitrage in the model. For this purpose, consider the possibility that the distributor in market $A$ (or an agent) can import the product from $B$. Arbitrage by distributor $A$ (in which he buys at the retail level abroad in order to find a cheaper source of supply than the available wholesale price) is not profitable if the margin between the wholesale price in market $A$ and the retail price in market $B$ is lower than the unit trade cost t. Formally, the no-arbitrage condition is

$$
w_{A} \leq p_{B}+t
$$

and in order to determine whether this condition is slack in equilibrium we insert the accommodation wholesale price in market $A$ and the retail price in market $B$. The critical threshold for retail markets to be segmented in this case is

$$
\widetilde{t}^{R}=\frac{S(b-1)}{6+7 S b}
$$

which is close to zero for $b$ close to 1 . Markets are consequently segmented at the retail level by the natural barrier $t$ for intermediate and high trade costs, i.e. $t \geq \widetilde{t}^{R}$. However, if markets are different in terms of price elasticity, then retail arbitrage would limit the scope for price discrimination at low trade costs, i.e. $t<\widetilde{t}^{R}$.

A second possibility might be arbitrage by final consumers. However, perfect consumer retail arbitrage is a strong assumption and inconsistent both with the fact that the bulk of PI occurs at the distributor level and with persistent differences in retail prices within the EU. There are good reasons to expect limited arbitrage of this kind even without restrictions on parallel trade. First, as noted 
above there are likely to be complementarities in retail services that cannot be provided by arbitrageurs. Second, there may be significant fixed costs in organizing cross-border retail trade. Third, there may be large information costs for consumers in determining product prices and characteristics for purposes of organizing arbitrage. Thus, we think our analysis of distributor-level PI is valid in the bulk of realistic circumstances.

\section{Two-Way Cross-Border Trade}

In this section we modify our model and permit two-way trade. Thus, we analyze the possibility of parallel imports into market $A$ from market $B$ and vice versa. We restrict our attention to the cases of wholesale price discrimination and an enforced uniform wholesale price. The distributors non-cooperatively set quantities in a Cournot-fashion in the two markets. A sub-game equilibrium in market $B$ with cross-border trade from $A$ to $B$ is therefore

$$
\begin{aligned}
& y_{A}=\frac{S\left(1+w_{B} b-2 w_{A} b-2 t b\right)}{3} \\
& y_{B}=\frac{S\left(1-2 w_{B} b+w_{A} b+t b\right)}{3}
\end{aligned}
$$

while the sub-game equilibrium in $A$, with cross-border trade from $B$ to $A$, is given by the optimal quantities (8) and (9). The manufacturing firm sets wholesale prices to maximize total profits

$$
\max _{w_{A}, w_{B}} X(w)\left(p_{A}(w)-c\right)+Y(w)\left(p_{B}(w)-c\right)-t\left(x_{B}+y_{A}\right)
$$

where the last term on the right hand side is the resources used in cross-border trade.

First, consider wholesale price discrimination. Prices block arbitrage from $A$ to $B$ if

$$
p_{B} \leq w_{A}+t
$$

for then cross-border trade in that direction would be unprofitable. It follows that the manufacturing firm can set the discriminatory wholesale prices given by (21) and (22), for sufficiently low trade costs, since these prices would block trade from $A$ to $B$. More specifically, these prices are arbitrage-free as long as 
the trade cost is below the threshold

$$
\widetilde{t}_{1}^{D 2}=\frac{(b-1) S}{6+3 S b} .
$$

Above this threshold two-way trade could potentially occur. However, it remains profitable for the manufacturing firm to set wholesale prices that actually eliminate trade from $A$ to $B$. Indeed, permitting two-way trade can never be profitable if the manufacturing firm can set discriminatory wholesale prices. If two-way arbitrage occurred the manufacturing firm could induce the same retail prices (remember that wholesale prices are perfect substitutes for this purpose) and reduce the total volume of cross-border trade by increasing $w_{A}$ and decreasing $w_{B}$. Thus, two-way parallel trade does not occur in equilibrium with discriminatory prices. Accordingly, the producer chooses wholesale prices that are arbitrage-free and solve the following equation

$$
\frac{S\left(1+w_{B} b-2 w_{A} b-2 t b\right)}{3}=0 .
$$

It follows that the first-order condition is

$$
\frac{b-1-3 w_{B} b+3 c b}{6 b}-\frac{S b\left(w_{B}-c\right)}{2}+\frac{t}{2}=0
$$

where the first term reflects the horizontal externality in market $A$, the second term reflects the vertical externality in market $B$ and the third term reflects the inefficiency in distribution. The optimal wholesale prices are

$$
\begin{aligned}
& w_{A}=\frac{2+b+3 S b}{6 b(S b+1)}+\frac{c}{2}-\frac{1+2 S b}{2(S b+1)} t, \\
& w_{B}=\frac{b-1}{3 b(S b+1)}+\frac{t}{(S b+1)}+c .
\end{aligned}
$$

In this situation there remains one-way parallel trade from $B$ to $A$ and its volume decreases in $t$, becoming zero if the trade cost is above the threshold

$$
\widetilde{t}_{2}^{D 2}=\frac{2+2 b^{2} S+b+S b-3 S b^{2} c-3 b c}{3 b(3+2 S b)} .
$$

For trade costs above this threshold, the manufacturing firm can block trade in both directions. It sets wholesale prices such that $x_{A}=0$ and $y_{B}=0$, where $x_{B}$ is given by equation (9) and $y_{A}$ is given by equation (57). The optimal 
wholesale prices are

$$
\begin{aligned}
& w_{A}=\frac{2+b-6 t b}{3 b}, \\
& w_{B}=\frac{1+2 b-6 t b}{3 b} .
\end{aligned}
$$

Finally, two-way trade is blocked for high trade costs and the discriminatory prices (23) and (24) comprise the equilibrium. The threshold for this outcome is

$$
\widetilde{t}_{3}^{D 2}=\frac{4+2 b-6 c b-3 S b^{2} c+S b+2 S b^{2}}{6 b(2+S b)}
$$

above which two-way cross-border trade is no longer a binding restriction for the manufacturing firm.

The wholesale and corresponding retail prices under wholesale price discrimination and two-way trade are illustrated in Figure 7. Two-way parallel trade changes the equilibrium wholesale prices for intermediate trade costs between the thresholds $\widetilde{t}_{1}^{D 2}$ and $\widetilde{t}_{3}^{D 2}$.

Next, consider the equilibrium with a uniform wholesale price. In this case two-way trade is potentially profitable for low trade costs. The first-order condition for the manufacturing firm is

$$
\frac{2-8 w-4 t+2 c}{9}+\frac{t(1+S b)}{3}+\frac{2 S(1-4 w b-2 t b+3 c b)}{9}=0
$$

and the optimal wholesale price is

$$
w=\frac{2+6 c+2 S+6 S c b-t-t S b}{8(1+S b)}
$$

and the equilibrium is unique. The volume of trade from $A$ to $B$, i.e. $y_{A}$, decreases in $t$ and for sufficiently high trade costs it is zero. The critical threshold is

$$
t_{1}^{U 2}=\frac{2\left(4+3 S b-b-3 b c-3 S b^{2} c\right)}{15(1+S b) b}
$$

Above this threshold, the manufacturing firm consequently blocks trade from $A$ to $B$ by solving

$$
y_{A}=\frac{S(1+w b-2 w b-2 t b)}{3}=0
$$




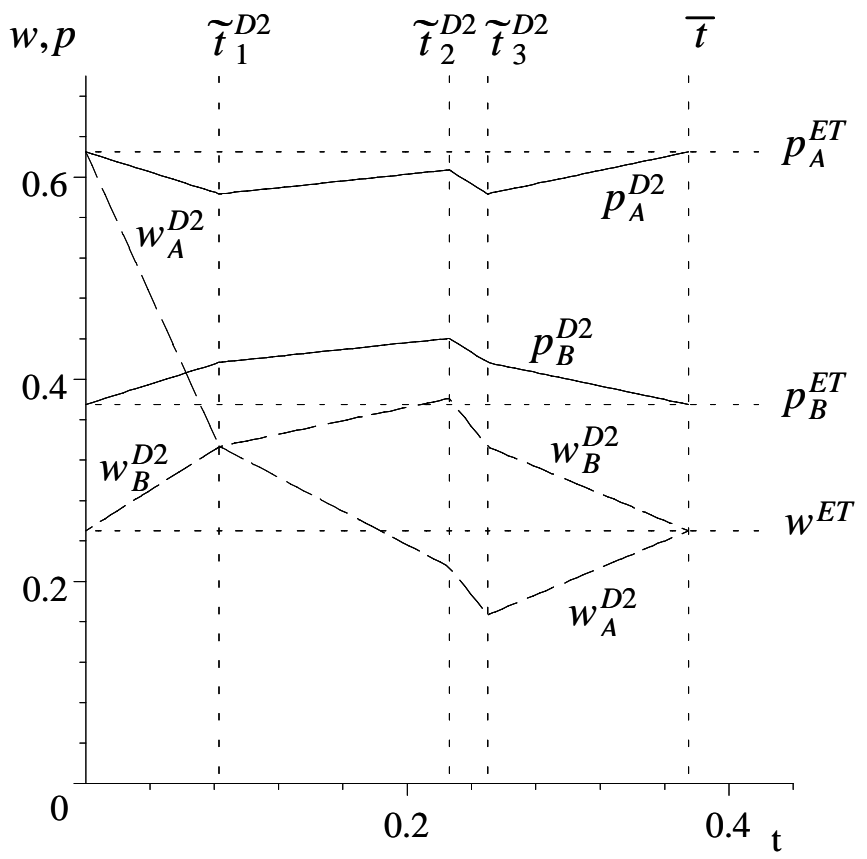

Figure 7: Wholesale and retail prices with price discrimination and two-way parallel trade $(S=1, b=2, c=1 / 4)$

and setting a wholesale price equal to

$$
w=\frac{1}{b}-2 t .
$$

This wholesale price quickly approaches the optimal uniform wholesale price with one-way trade, given by equation (30), from above and the two are equal at the threshold

$$
t_{2}^{U 2}=\frac{9 S b+16-4 b-9 S b^{2} c-12 b c}{6 b(5+3 S b)} .
$$

Above this threshold, trade from $A$ to $B$ is blocked by the unit trade cost and the manufacturing firm can set the same uniform wholesale price as with oneway trade, i.e. the equilibrium given by (30) and (31). The wholesale price is arbitrage-free for any trade cost greater than

$$
\widetilde{t}_{3}^{U 2}=\widetilde{t}^{U}=\frac{(1-c)(4+3 S b)}{10+6 S b} .
$$


The uniform wholesale price and the corresponding retail prices are plotted in Figure 8. It is worth noting that retail prices are higher in both markets with two-way trade, i.e. for $t<\widetilde{t}_{2}^{U} 2$, compared to the retail prices with one-way trade, $p_{A}^{U}$.and $p_{B}^{U}$ (not shown in Figure 8). Here, the restriction that there be a single uniform price makes it yet harder for the manufacturer to limit the cost of parallel trade, now happening in both directions, thereby pushing up retail prices even more.

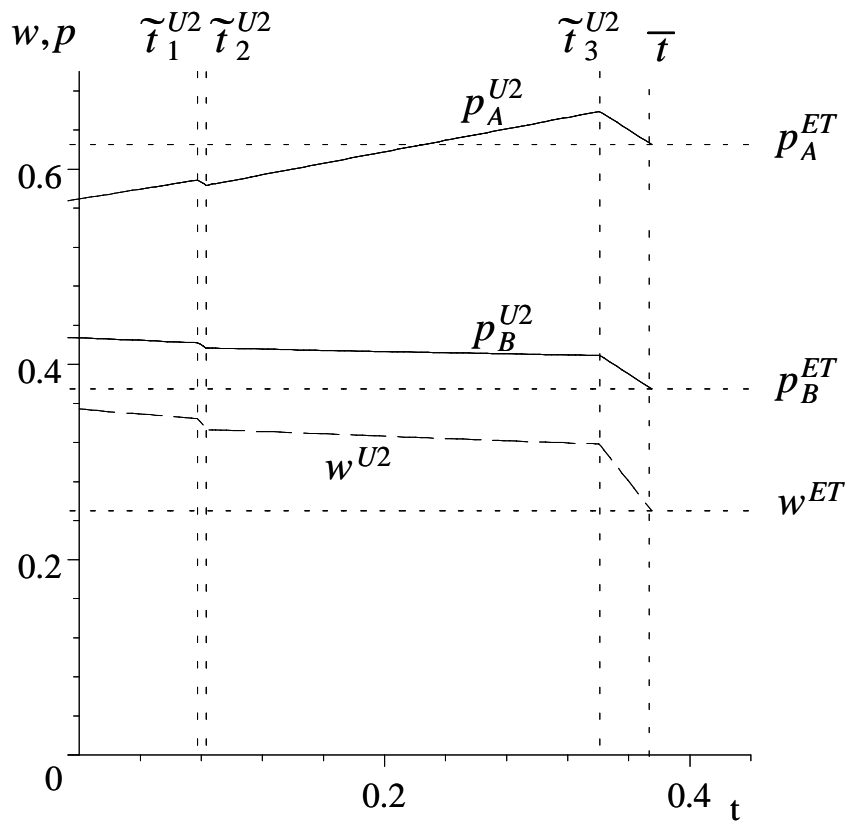

Figure 8: Retail prices and the uniform wholesale price with two-way parallel trade $(S=1, b=2, c=1 / 4)$

\section{Conclusion}

We developed a model in which a manufacturing firm owns an intellectual property right in two markets but its ability to limit parallel imports from one market to the other is exhausted. In this environment, the firm has the ability to set wholesale prices - either discriminatory or uniform depending on the regulatory regime - to its independent distributors in the two locations. It will use 
its available instruments to maximize profits within the vertical price control framework. There are three essential trade-offs for the manufacturer. It wishes to restrict the extent of competition from parallel imports in market $A$ (a horizontal externality), limit the amount of trade because it wastes real resources in transport costs (inefficient distribution), and avoid the double-markup problem in market $B$ arising from the inability to set an efficient wholesale price (a vertical externality).

We considered two principal policy regimes: a discriminatory pricing regime permitting varying wholesale prices for each distributor and a uniform pricing regime forcing the manufacturing firm to set a common wholesale price for all distributors. We also analyze a regime that requires the manufacturing firm to set wholesale prices that cover the marginal cost of production, .

Our analysis turned up some interesting results. The equilibrium analysis shows that discriminatory pricing, on the one hand, may result in partial retail price divergence for low and high trade costs. The incentive to minimize the resources wasted in trade activities by reducing the retail price gap between markets counteracts the underlying incentive to induce different retail prices in the two markets. The problem with inefficient distribution is particularly severe for intermediate trade costs since the trade barrier does not block parallel imports but reduces revenues significantly. Uniform pricing, on the other hand, results in retail prices higher than the monopoly level for high trade costs, close to the prohibitive level. For high trade costs the manufacturing firm has a strong incentive to impede parallel imports, but in order to achieve this goal the firm must raise retail prices in both markets. In contrast, for low trade costs it results in price convergence as well as a pro-competitive effect in the import market. The manufacturing firm is willing to accept a larger volume of parallel imports and the pro-competitive effect in market $\mathrm{A}$ is substantial.

The welfare analysis shows that, depending on circumstances, either discriminatory pricing or uniform pricing may be more beneficial. This finding has important implications for competition policy. A regulation that makes price discrimination illegal per se if it impedes parallel imports may not be optimal. Requiring the manufacturing firm to charge a uniform wholesale price may be optimal for low trade costs when the pro-competitive effect is substantial but may have a severe negative effect on consumer welfare when trade costs are high as the primary effect is that retail prices increase in all markets. Further, when there is a possibility of two-way parallel trade the uniform-price restriction can raise retail prices at even low trade costs. These consequences, presumably 
unintended, of the pricing restraint suggests that an effects-based approach in competition policy is advisable under these circumstances.

Last, but not least, the welfare analysis show that market integration and competition law may be important complements in a policy perspective. This complementarity works both ways for low and intermediate trade costs. A reduced unit trade cost makes uniform pricing more attractive for consumers. Correspondingly, adopting a uniform pricing regime enhances the welfare incentives to continue the gradual dismantling of trade barriers. 


\section{References}

[1] Chen, Y. and K. E. Maskus (2005), "Vertical Pricing and Parallel Imports," Journal of International Trade and Economic Development 14: 1-18.

[2] Ganslandt, M. and K. E. Maskus (2003), "Vertical Restraints, Distribution, and the Price Impact of Parallel Imports: Implications for the European Union and Sweden," in K. Lundvall, ed., High Prices in Sweden - A Result of Poor Competition? (Stockholm: Swedish Competition Authority), 160223.

[3] Ganslandt, M. and K. E. Maskus (2004), "The Price Impact of Parallel Trade in Pharmaceuticals: Evidence from the European Union," Journal of Health Economics 23: 1035-1057.

[4] Ganslandt, M. and K. E. Maskus (2007), "Vertical Distribution, Parallel Trade, and Price Divergence in Integrated Markets," European Economic Review (forthcoming)

[5] Géradin, D. and N. Petit (2007), "Price Discrimination under EC Competition Law: The Need for a Case-by-Case Approach," GCLC Working Paper 07/05

[6] Hilke, J. C. (1988), "Free Trading or Free Riding: an Examination of the Theories and Available Evidence on Gray Market Imports," World Competition 32: 75-92.

[7] Malueg, D. A. and M. Schwartz (1994), "Parallel Imports, Demand Dispersion, and International Price Discrimination," Journal of International Economics 37: 187-196.

[8] Maskus, K. E. and Y. Chen (2002), "Parallel Imports in a Model of Vertical Distribution: Theory, Evidence, and Policy," Pacific Economic Review 7: 319-334.

[9] Matsumura, T. (2003), "Consumer-benefiting Exclusive Territories," Canadian Journal of Economics 36: 1007-1025.

[10] National Economic Research Associates (1999), The Economic Consequences of the Choice of Regime in the Area of Trademarks (London: National Economic Research Associates). 
[11] Raff, H. and N. Schmitt (2005), "Endogenous Vertical Restraints in International Trade," European Economic Review, Vol 49, Issue 7, October, $1877-1889$

[12] Richardson, M. (2002), "An Elementary Proposition Concerning Parallel Imports," Journal of International Economics 56: 233-245.

[13] Whish, Richard (2003), Competition Law, 5th edition, LexisNexis UK, London 